\title{
Uma bicoca na costa da África: a política espanhola para o tráfico de escravos, o Reglamento de Comercio Libre e as fronteiras ibéricas na América do Sul (1776-1778)*
}

por

Gabriel Aladrén ${ }^{1}$

Universidade Federal Fluminense

O Tratado de Santo Ildefonso, firmado entre Espanha e Portugal em 1777, previa a demarcação de limites entre os impérios ibéricos no Novo Mundo. Algumas de suas cláusulas também determinavam que Portugal cedesse à Espanha as ilhas de Fernando Pó e Ano Bom, no Golfo da Guiné. Carlos III e Floridablanca, seu secretário de estado, desejavam obter um território na costa africana para permitir a atuação direta de comerciantes espanhóis no tráfico transatlântico de escravos. Este artigo examina os interesses e as condições que suscitaram o acordo para transferência da soberania das ilhas africanas e analisa os motivos que impediram a Espanha de firmar sua presença no comércio negreiro. Argumenta que para compreender a política espanhola para o tráfico de escravos nas décadas de 1770 e 1780 é preciso examiná-la à luz do processo de elaboração do "Reglamento de Comercio Libre» e dos conflitos territoriais hispano-portugueses na América do Sul.

Palavras-Chave: tráfico de escravos; Tratado de Santo Ildefonso; reformas bourbônicas; diplomacia.

Cómo CitAR este artículo / Citation: Aladrén, Gabriel, "Uma bicoca na costa da África: a política espanhola para o tráfico de escravos, o Reglamento de Comercio Libre e as fronteiras ibéricas na América do Sul (1776-1778)", Revista de Indias, LXXVII/270 (Madrid, 2017): 585-615, doi:10.3989/revindias.2017.019.

* Pesquisa financiada por bolsa de pós-doutorado da Fundação de Amparo à Pesquisa do Estado de São Paulo (FAPESP), processo n. 2012/19759-4. Uma versão preliminar deste texto foi discutida na linha de pesquisa sobre escravidão do Lab-Mundi (Universidade de São Paulo), coordenado por Rafael Marquese. Agradeço aos colegas pelos valiosos comentários e sugestões.

${ }^{1}$ gabrielaladren@yahoo.com.br ORCID iD: http://orcid.org/0000-0003-4560-6850. 
A história das disputas políticas, militares e diplomáticas entre Portugal e Espanha pelos domínios coloniais na América do Sul é largamente conhecida e investigada, particularmente o longo processo de demarcação das fronteiras na região do Rio da Prata. Tradicionalmente, os historiadores examinam o tema enfatizando os conflitos em torno dos limites territoriais entre os Estados, a questão dos direitos de comércio e navegação, o problema do contrabando e da passagem de gado, e as alianças transnacionais das elites regionais.

Os dirigentes que assumiram a liderança das formações políticas criadas na esteira do desmantelamento dos impérios ibéricos na América do Sul se depararam com a necessidade de consolidar a ordem interna, assegurar a integridade territorial e definir as fronteiras dos emergentes Estados. Esse contexto impulsionou o surgimento de historiografias nacionais, que buscavam conferir um passado coerente às novas unidades políticas, legitimando-as e dotando-as de projetos de futuro. Naturalmente, os conflitos militares e os tratados de limites celebrados entre Espanha e Portugal no período colonial receberam espaço privilegiado nas historiografias da Argentina, do Brasil e do Uruguai, muitas vezes em estreita relação com a produção de diplomatas e políticos que buscavam argumentos históricos para defenderem as posições de seus respectivos governos nas diversas negociações bilaterais que percorreram todo o século XIX e chegaram a adentrar o século XX.

Esses interesses condicionaram a leitura dos tratados diplomáticos, de modo que a historiografia tende a examiná-los quase exclusivamente do ponto de vista de suas consequências para a demarcação de fronteiras. No entanto, tal perspectiva empobrece a análise, especialmente no que se refere aos tratados de 1777 e 1778, firmados por Portugal e Espanha após um período de quinze anos de guerras e conflitos militares intermitentes na região platina. Algumas de suas cláusulas, pouco conhecidas, determinavam que Portugal cedesse à Espanha as ilhas de Fernando Pó e Ano Bom, no golfo da Guiné. Como veremos, a intenção de Carlos III e de Floridablanca, seu Secretário de Estado, era obter um território na costa africana para estabelecer a infraestrutura necessária à atuação direta de comerciantes espanhóis no tráfico de escravos, livrando a Espanha da antiga dependência de fornecedores estrangeiros.

Neste trabalho, meu objetivo é examinar os interesses e condições que suscitaram o acordo hispano-português para a transferência de soberania das ilhas africanas e analisar os motivos que impediram a Espanha de consolidar sua presença no comércio negreiro transatlântico nas décadas de 1770 e 1780 . Argumento que, para compreender a política espanhola direcionada ao tráfico de escravos e ao litígio dos limites na América do Sul durante o reinado de Carlos III é necessário examiná-la à luz das discussões travadas em torno do 
projeto de liberação do comércio, o principal objetivo dos reformadores espanhóis após a Guerra dos Sete Anos. Tal articulação, que se materializava na esfera da geopolítica e da diplomacia, ficou evidente entre os anos de 1776 e 1778, quando foram celebrados os tratados hispano-portugueses e aprovado o Reglamento de Comercio Libre no império espanhol.

\section{DIPLOMACIA E SISTEMA INTERESTATAL NOS TEMPOS MODERNOS}

Segundo Sergio Pistone, a expressão relações internacionais identifica o complexo de interações estabelecidas entre os Estados, implicando a separação entre as esferas externa e interna dos mesmos. Tal distinção só teria validade com a existência de uma pluralidade de Estados soberanos, fenômeno que ocorreu na Europa moderna como produto da desintegração do feudalismo. Com efeito, considera-se a Paz de Westfália (1648) um marco que reconheceu e consolidou o monopólio da força dentro do Estado, a sua soberania absoluta no plano internacional e os princípios do direito internacional, ou direito das gentes. Esses fatores concorreram para a criação de um «sistema de Estados», definido pelo estabelecimento de uma hierarquia entre grandes, médias e pequenas potências na qual nenhuma tem força suficiente para subjugar todas as demais, ainda que uma delas possa exercer temporariamente um papel hegemônico, ou dominante, em relação ao conjunto² .

A noção de um sistema político internacional é essencial para o estudo da política externa e das relações entre os Estados modernos, uma vez que a própria diplomacia é uma invenção institucional da era moderna. Na Europa medieval não existia claramente um conjunto de unidades políticas homogêneas, ou algo semelhante a um sistema estatal internacional. Havia uma série de unidades políticas difusas, com instâncias jurídicas sobrepostas geograficamente, o que ensejava a proliferação de «múltiplas vassalagens, suseranias assimétricas e enclaves irregulares». Segundo Perry Anderson, «neste intrincado labirinto não havia possibilidade de surgimento de um sistema diplomático formal, porque não havia uniformidade ou equivalência dos parceiros». É evidente que existiam atividades de natureza diplomática, como as embaixadas e a troca de visitas entre príncipes de territórios distintos ou entre um príncipe e seu suserano. Porém, tais atividades eram esporádicas, não remuneradas e não constituíam um elemento estável e regulador da interação entre os Estados. Somente com o surgimento das monarquias centralizadas da era moderna estruturou-se «um sistema formalizado de pressão e intercâmbio

\footnotetext{
2 Pistone, 1997: 1089-1099.
} 
entre Estados, com o estabelecimento das novas instituições das embaixadas fixas e recíprocas no exterior, chancelarias permanentes para as relações exteriores e comunicações e relatórios diplomáticos secretos» ${ }^{3}$.

Immanuel Wallerstein e Giovanni Arrighi, ao estudar as relações entre os Estados nas eras moderna e contemporânea, recorrem ao conceito de sistema interestatal. Sua origem remonta à publicação da obra The modern world-system, publicada em 1974, por Wallerstein, embora ele ainda não tivesse utilizado a expressão na ocasião. Nessa obra, o autor apresenta sua interpretação do capitalismo enquanto um sistema mundial moderno, definido pela ligação simbiótica entre a economia-mundo capitalista e o sistema interestatal. Segundo Wallerstein, o sistema de relações internacionais entre os Estados modernos europeus é crucial para o próprio funcionamento da economia mundial, de modo que «o capitalismo pôde florescer precisamente porque a economia-mundo continha em seus limites não um, mas uma multiplicidade de sistemas políticos $\rangle^{4}$. Portanto, as diversas formas de interação política entre os Estados, como a diplomacia ou a guerra, devem ser examinadas a partir dos condicionamentos impostos pela dinâmica da economia-mundo capitalista.

Giovanni Arrighi considera que «a força da conceitualização de Wallerstein é sua ênfase na unidade fundamental entre o capitalismo e o moderno sistema de governo. Sua fraqueza reside na sua tendência a obscurecer todas as distinções analíticas entre os dois termos desta relação». Arrighi alega existir certa autonomia do sistema interestatal em relação à economia-mundo, na medida em que a «segmentação da economia-mundo em jurisdições políticas concorrentes não necessariamente beneficia a acumulação de capital» ${ }^{5}$.

A despeito de suas diferenças, ambos os autores acreditam que os conflitos e alianças na esfera das relações internacionais estão relacionados a mudanças na divisão internacional do trabalho, tornando possível e necessário identificar razões econômicas para as guerras e os alinhamentos diplomáticos ${ }^{6}$. As relações internacionais e o comércio internacional -expressões e materializações do sistema interestatal e da economia-mundo capitalista- não podem ser objeto de exame isolado, pois fazem parte de uma mesma unidade conceitual ${ }^{7}$.

3 Anderson, 1995: 37-38. Charles Tilly afirma que, em fins do século XV, estava sendo criado na Europa «um sistema de Estados interconectados, ligados por tratados, embaixadas, casamentos e comunicação extensiva». Em sua acepção, os Estados constituem «um sistema quando eles interagem uns com os outros regularmente e na medida em que esta interação afeta o comportamento de cada Estado». Cf. Tilly, 1990: 163-164.

4 Wallerstein, 1974: 348.

5 Arrighi, 1993: 153; 1996: 27-85.

6 Hopkins, 1982: 25.

7 Hopkins y Wallerstein, 1982: 58-59. 
Neste artigo, dou preferência à utilização do conceito de «sistema interestatal», pois ele me parece ter um alcance explicativo maior do que o de «sistema de Estados», uma vez que adquire funcionalidade quando pensado conjuntamente com o conceito de economia-mundo. Enquanto a ideia do sistema de Estados privilegia a ação política e estabelece uma distinção clara entre as esferas interna e externa aos Estados, a de sistema interestatal exige que o exame da diplomacia, das guerras e dos alinhamentos políticos internacionais seja integrado à análise do comércio, da divisão internacional do trabalho, dos conflitos sociais e dos interesses econômicos dos grupos de poder, que repercutem tanto no interior dos Estados como no plano exterior. Tal perspectiva se conjuga com a proposta de analisar o tráfico negreiro como instrumento das políticas coloniais e objeto da rivalidade interimperial característica da época moderna ${ }^{8}$. A combinação dessas abordagens é valiosa, na medida em que permitirá examinar e avaliar as estratégias políticas e diplomáticas dos impérios ibéricos nas décadas de 1770 e 1780, particularmente as direcionadas ao tráfico de escravos, num quadro marcado pela perda de sua competitividade perante a Inglaterra e a França na esfera da economia-mundo.

\section{GUERRA E REFORMAS ILUSTRADAS NO ATLÂNTICO SUL}

No século XVIII, as monarquias ibéricas dependiam de uma inserção subordinada no sistema interestatal para assegurarem seus domínios coloniais ${ }^{9}$. A Guerra dos Sete Anos expressou o acirramento da disputa entre Grã-Bretanha e França pela primazia no mundo atlântico. A Espanha assumiu inicialmente uma posição de neutralidade, quebrada em $1761 \mathrm{com}$ a renovação do Pacto de Família, que estabelecia uma aliança defensiva entre os Bourbon espanhóis e franceses. Logo a Grã-Bretanha declarou guerra à Espanha, tomando Havana e Manila em 1762, portos estratégicos do sistema de comércio marítimo do império espanhol. Portugal também abandonou a neutralidade, se posicionando ao lado da Inglaterra ${ }^{10}$. $\mathrm{O}$ modo como o conflito atingiu as monarquias espanhola e portuguesa, e as respostas que seus administradores elaboraram para lidar com suas consequências guardam muitas semelhanças,

${ }^{8}$ Novais, 1989. Alencastro, 2000.

9 Tal juízo tem maior aplicabilidade ao império português do que ao espanhol, visto que o último se manteve, a despeito do legado negativo da Paz de Utrecht, uma potência importante no cenário internacional setecentista, exibindo força militar e capacidade de arrecadação fiscal respeitáveis. Novais, 1989: 17-56. Stein e Stein, 2000: 136-156.

10 Para um panorama atualizado do conflito cf. Elliott, 2006: 292-324. 
demonstrando que os impérios ibéricos estavam unificados na mesma estrutura, que condicionava mutuamente a sua dinâmica histórica ${ }^{11}$.

A guerra expôs aos estadistas espanhóis a instabilidade dos fundamentos do império. O programa de reformas da monarquia, iniciado pelos Bourbon antes da guerra, foi acelerado, visando reforçar o sistema de defesa militar ultramarino e incrementar o comércio e o dinamismo econômico das colônias. Áreas até então periféricas no sistema de extração de tributos do império espanhol, como Cuba, Nova Granada e o Rio da Prata receberam atenção dos reformadores, que buscaram sedimentar alianças seletivas com as elites criollas e fomentar a escravidão, com a ideia de que sua expansão fortaleceria os laços coloniais ${ }^{12}$.

A monarquia portuguesa também percebeu a fragilidade das defesas militares do Brasil durante a Guerra dos Sete Anos. O complexo comercial do Atlântico português se mostrou vulnerável às incursões de contrabandistas, ao passo que os territórios do sul da América eram disputados pelos espanhóis. Em 1763, a capital do Estado do Brasil foi transferida de Salvador para o Rio de Janeiro, em razão da importância estratégica da cidade nas redes de comércio da mineração e no sistema de defesa do Atlântico Sul. As reformas arquitetadas pelo Secretário de Estado do Reino, o marquês de Pombal, visavam reorganizar a administração econômica e política do império. Durante a década de 1760, os rendimentos auferidos com a mineração diminuíram e a política de incentivos à diversificação agrícola avançou, embora seus resultados tenham aparecido com mais força apenas na década de 1790 , tendo se beneficiado de deslocamentos críticos no mercado internacional de produtos tropicais ${ }^{13}$.

As disputas territoriais entre Portugal e Espanha na região platina eram antigas, tendo se acirrado desde a fundação da Colônia do Sacramento em 1680. Ponto de discórdia e objeto de batalhas, a praça mercantil se manteve

11 Me baseio na ideia de «sistema atlântico ibérico», elaborada por Berbel, Marquese e Parron, 2010: 21-41.

12 Adelman, 2006: 56-100. Berbel, Marquese e Parron, 2010: 75-85. Allan Kuethe e Kenneth Andrien realizaram, recentemente, um importante balanço da produção historiográfica sobre as reformas bourbônicas. Cf. Kuethe e Andrien, 2014: 12-26. Deve-se notar que existiam objetivos múltiplos e contraditórios entre os estadistas espanhóis, de modo que seria mais adequado falar de diversos reformismos ao invés de um só. Não existia uma ideologia uniforme compartilhada pelos reformadores e, além disso, eles precisavam equilibrar os interesses de vários grupos de pressão que atuavam no interior do império espanhol. As medidas concretas implementadas também buscavam se adequar às condições específicas de cada uma das regiões do vasto império americano.

13 Alden, 2004: 527-592. Arruda, 1980: 604-655. Maxwell, 1999: 69-90. 
sob domínio português a despeito de cercos e ocupações espanholas. Em 1750, o Tratado de Madrid previa a troca da Colônia pelas Missões Orientais. Mudanças estratégicas na política imperial portuguesa com a ascensão de Pombal e a resistência dos índios missioneiros à desocupação na Guerra Guaranítica (1754-1756) levaram a uma mudança de planos. Em 1761, o Tratado de Madrid foi anulado. Em 1762, durante a Guerra dos Sete Anos, os castelhanos ocuparam a vila de Rio Grande e a Colônia do Sacramento, esta última devolvida após o Tratado de Paris. Entre 1763 e 1775 ocorreram alguns enfrentamentos locais, mas poucas mudanças na configuração territorial. Os espanhóis procuraram isolar a Colônia do Sacramento, bloqueando o porto e controlando fortificações e postos de passagem na Banda Oriental e no Continente de São Pedro ${ }^{14}$.

Os portugueses, que tentavam retomar Rio Grande sem sucesso, encontraram nova oportunidade no início de 1776. Em abril do ano anterior, a Espanha organizara uma grande expedição punitiva contra o Dey de Argel, acusado de promover a pirataria no Mediterrâneo e incitar o rei do Marrocos a se rebelar contra os espanhóis. Tratava-se de uma demonstração de força. Depois da vitória no Norte da África, a expedição possivelmente rumaria para o Rio da Prata. Porém, o ataque a Argel realizado no início de julho foi um grande fracasso, com pesadas perdas entre os espanhóis. Na mesma época, o Secretário de Estado espanhol Grimaldi recebeu notícias sobre a movimentação de tropas luso-brasileiras no sul. De fato, o marquês de Lavradio havia mandado organizar forças terrestres e navais, que também contariam com o apoio das guerrilhas rio-grandenses. Grimaldi propôs conversações de paz. Pombal aceitou, mas queria antes de tudo aproveitar a fraqueza espanhola e expulsar os castelhanos do Continente de São Pedro. Depois, projetava obter o apoio da Inglaterra para manter a Colônia do Sacramento e assim assegurar o tão desejado domínio territorial contínuo até a margem setentrional do Rio da Prata. Em abril de 1776, os portugueses conseguiram retomar Rio Grande.

Contudo, duas situações fariam a balança pender para o lado da Espanha, colocando-a em franca vantagem. Primeiro, a declaração da independência dos Estados Unidos em julho de 1776 implicava a escalada da guerra das treze colônias, o que tornaria remota a possibilidade de Portugal contar com o apoio militar e diplomático britânico. Ao mesmo tempo, Carlos III ordenou a organização de uma poderosa expedição, sob o comando de Pedro de Cevallos, reunindo um exército de aproximadamente dez mil homens que se

14 O relato dos conflitos se baseia em Alden, 1961: 55-74. 
dirigiu à América do Sul em agosto ${ }^{15}$. O plano era ambicioso: visava derrotar os portugueses e instalar o Vice-Reino do Rio da Prata, tendo Buenos Aires como capital. Tropas foram posicionadas em pontos da fronteira hispano-portuguesa na Península e uma frota foi enviada para patrulhar as águas até as Canárias, com o fim de evitar o envio de reforços portugueses ao Brasil. No Atlântico sul, os espanhóis conquistaram facilmente a ilha de Santa Catarina. Seu objetivo era rumar para a vila de Rio Grande, mas uma tempestade impediu a entrada das embarcações na barra. Dirigindo-se para o Rio da Prata, Cevallos tomou a Colônia do Sacramento, após a rendição dos portugueses em junho de 1777. Entretanto, Espanha e Portugal haviam reiniciado as negociações, facilitadas por mudanças políticas ocorridas em ambas as coroas.

$\mathrm{Na}$ Espanha, a equipe ministerial de Carlos III havia sofrido uma importante reestruturação ao longo de 1776, com a nomeação de José de Gálvez para a Secretaria de Índias e a de José de Moñino, o conde de Floridablanca, para a Secretaria de Estado, substituindo Grimaldi. Os últimos anos da gestão Grimaldi foram marcados por episódios desastrosos, como a crise das Malvinas e o fracasso da expedição de Argel. Ele seguira uma política de organização militar baseada no modelo prussiano que aumentara os gastos fiscais a limites insustentáveis, produzindo um altíssimo déficit entre 1775 e 1777. Floridablanca foi nomeado em novembro de 1776, mas só assumiria em fevereiro do ano seguinte, deparando-se com um cenário favorável na América do Sul e com uma nova disposição dos portugueses para a negociação ${ }^{16}$. $\mathrm{O}$ rei José I faleceu em fevereiro de 1777 e, em março, o marquês de Pombal foi afastado. Tais acontecimentos resultariam em mudanças importantes na orientação política do império português ${ }^{17}$.

O embaixador português em Madrid, Francisco de Sousa Coutinho, procurou Floridablanca para retomar as negociações. Tanto espanhóis como portugueses estavam dispostos a buscar uma aproximação, pelo menos momentaneamente. Os primeiros esperavam neutralizar os britânicos e assegurar uma maior autonomia em relação aos franceses. Os portugueses estavam em uma

15 Os historiadores atribuem números que variam de nove a vinte e um mil. Provavelmente, diferenças tão gritantes decorrem, para além dos exageros e equívocos, de uma confusão entre a quantidade de soldados e oficiais do exército e o total de indivíduos que fizeram parte da expedição. Os trabalhos que se debruçaram sobre os documentos da expedição afirmam que a mesma contava com quase dez mil homens do exército. Além deles, estima-se que a tripulação das embarcações (vinte de guerra e mais de noventa de transporte), girava entre seis e oito mil pessoas. Um exame recente e detalhado pode ser encontrado em Rico Bodelón, 2013: 266-277.

16 Delgado Ribas, 2007: 371-375.

17 Maxwell, 2004: 60-61. 
situação complicada, inferiorizados militarmente e sem poder contar com o apoio da Inglaterra. Os tratados de 1777 e 1778 foram assinados em um cenário amplamente favorável à Espanha em termos militares e diplomáticos, o que permitiu aos estadistas espanhóis negociarem tendo em mira interesses estratégicos, para além das disputas de limites territoriais na América do Sul.

\section{O Tratado Preliminar de Limites e o «Comercio libre»}

O Tratado Preliminar de Limites, firmado em Santo Ildefonso no dia primeiro de outubro de 1777, consagrou a reorganização territorial elaborada por Alexandre de Gusmão e José de Carvajal para o Tratado de Madrid, com pequenas modificações. Assim como em 1750, as instruções para a definição da linha na fronteira norte da América do Sul eram bastante imprecisas, até em razão do desconhecimento geográfico, mas visavam antes de tudo manter o domínio espanhol sobre a bacia do Orinoco e o português sobre a do Amazonas. Na fronteira oeste, grosso modo, mantinham-se os mesmos limites. No Pacífico, as Filipinas, que pela divisão de Tordesilhas deveriam ser portuguesas, foram novamente reconhecidas como domínio espanhol. As maiores alterações em termos de partilha territorial ficariam no sul da América: além de confirmarem a posse da Colônia do Sacramento, os espanhóis não precisariam entregar os Sete Povos das Missões aos portugueses, conforme previa o Tratado de Madrid. Em suma, a Espanha tinha alcançado seu maior objetivo, o controle da navegação e do comércio no Rio da Prata ${ }^{18}$.

Isso não era tudo. Floridablanca, querendo se desembaraçar do conflito na América do Sul para avançar a política reformadora do sistema comercial espanhol, optou por devolver a ilha de Santa Catarina e não reclamar a posse da vila de Rio Grande, decisão criticada por alguns de seus opositores, entre eles o conde de Aranda. Floridablanca considerava que, a despeito das vantagens que poderiam oferecer, a manutenção desses territórios seria economicamente muito custosa, entre outros motivos porque os espanhóis não contavam com uma rede de povoamento e produção que lhes servisse de retaguarda. Além disso, o ministro espanhol sabia que Portugal não abriria mão de Santa Catarina e Rio Grande facilmente. Tendo assegurado o domínio sobre o Rio da Prata, o importante era garantir a paz e obter vantagens comerciais e militares dos portugueses ${ }^{19}$.

\footnotetext{
18 Lucena Giraldo, 1993: 21-39. Reis, 1972: 368-379. Goes, 1991: 101-119.

19 Correndo o risco de afiançar o que pode ser uma justificativa ex post facto, me baseio na defesa que Floridablanca fez da sua gestão em 1788. Cf. Memorial presentado al rey Car-
} 
Os tratados de 1777 e 1778 devem ser examinados num cenário mais amplo. O grande foco dos reformadores espanhóis desde 1776 foi alteração do sistema de comércio do império. Essa operação era delicada e dependia não apenas da superação de obstáculos impostos pelas comunidades mercantis de Cádiz e da Cidade do México, mas também da obtenção de segurança e autonomia no quadro das relações internacionais. Só assim a Espanha teria força suficiente para enfrentar uma possível guerra contra a Inglaterra sem ter de se submeter totalmente aos aliados franceses. Este último objetivo não era menor, pois o projeto de comércio livre que estava sendo elaborado confrontava interesses econômicos da França ${ }^{20}$.

Floridablanca formulou sua política econômica com base nas ideias de Pedro Rodríguez Campomanes, as quais contavam com o apoio de Grimaldi e do rei Carlos III $^{21}$. O eixo central da proposta de Campomanes era o fim do monopólio de Cádiz, considerada a única maneira de promover o comércio, a riqueza e o poder do império ${ }^{22}$. Na década de 1770 , ele incorporou novos objetivos, particularmente o fomento da «indústria popular» na Espanha. Para isso, era necessário impedir a entrada do capital mercantil em alguns setores manufatureiros, a fim de aumentar a renda do campesinato sem prejudicar o poder da aristocracia rural. Os pequenos produtores da indústria popular (roupas grosseiras, calçados, móveis etc.) seriam protegidos com a criação de um mercado cativo. Segundo Josep Delgado, tratava-se de uma resposta à possível eclosão de novos motins como o de Esquilache, de 1766, devido ao aumento da pressão fiscal sobre os camponeses e artesãos. Com isso, Campomanes se afastava do modelo mercantilista para a indústria visando apaziguar tensões sociais na Península. $\mathrm{O}$ proibicionismo como meio de apoio à industria popular orientou a política tarifária de Floridablanca, como pode se observar no decreto do comércio livre de 1778 e nos Aranceles del comercio exterior de 1782. Isso trazia duas implicações: primeiro, o objetivo mercantilista de proteção indiscriminada da indústria espanhola foi substituído por

los III y repetido a Carlos IV por el Conde de Floridablanca, San Lorenzo, 10 de Octubre de 1788 (Ferrer del Rio, 1867: 307-308).

20 Sobre o Reglamento para el comercio libre de 1778, cf. Stein y Stein, 2003: 143-185. A influência francesa sobre a política econômica e a política exterior espanhola após o terceiro pacto de família (1761) não foi tão decisiva quanto se costuma pensar. Mesmo no período de maior estreitamento, isto é, até a crise das Malvinas (1770), a França não logrou obter da Espanha as vantagens comerciais desejadas. Depois de 1770, Carlos III seguiu política ainda mais autônoma, às vezes francamente contrária aos interesses franceses. Cf. Delgado Ribas, 2007: 340-356. Kuethe e Blaisdell, 1991: 579-607.

21 Delgado Ribas, 2007: 377.

22 Berbel, Marquese e Parron, 2010: 76-77. 
uma proteção seletiva, definida mais por razões sociais e de política interna do que econômicas; segundo, sua aplicação exigia a redefinição das relações comerciais com a França, a principal fornecedora de bens que concorriam com os produzidos pela indústria popular. Com efeito, pode-se notar que a partir de 1776 houve um aumento do receio dos estadistas espanhóis em relação aos franceses. O sentimento antifrancês estava presente em Floridablanca e Aranda, apesar de sua rivalidade, e também em José de Gálvez, até então visto com bons olhos por Paris ${ }^{23}$.

A Espanha precisava consolidar uma aliança com Portugal, de modo a assegurar uma posição mais vantajosa no quadro internacional. Por isso Floridablanca não hesitou em devolver Santa Catarina e desistir de Rio Grande nas negociações de 1777 . Os portugueses se mostraram dispostos a conceder vantagens em troca da liberalidade de Carlos III. Propunham uma aliança defensiva, direitos de nação mais favorecida em acordos comerciais e ofereciam duas ilhas no Golfo da Guiné, Fernando Pó e Ano Bom, para que os espanhóis pudessem realizar, em primeira mão, o tráfico negreiro ${ }^{24}$.

O Tratado Preliminar de Limites formalizava as negociações. Além das disposições para a divisão territorial, incluía alguns artigos separados que deveriam permanecer secretos. O primeiro estipulava que o tratado deveria servir de base a outros três: um de "perpétua e indissolúvel aliança», outro de comércio e um terceiro definitivo de limites para a América meridional. O segundo artigo determinava uma espécie de aliança defensiva, impedindo Portugal e Espanha de franquear o trânsito de inimigos da outra nação ou de contrabandistas em seus portos e territórios do Atlântico Sul, e, em caso de guerra, os contratantes não poderiam permitir que seus domínios servissem direta ou indiretamente de auxílio para atacar o aliado. No terceiro e quarto artigos, «desejando Sua Majestade Fidelíssima corresponder à magnanimidade de Sua Majestade Católica», Portugal cedia à Espanha as ilhas de Ano Bom e de Fernando Pó ${ }^{25}$.

No dia vinte e quatro de março de 1778, Espanha e Portugal firmaram o Tratado de Amizade, Garantia e Comércio, resumindo nele os três previstos no ano anterior. No décimo terceiro artigo definia-se a transferência de sobe-

23 Delgado Ribas, 2007: 377-385. Para sustentar seu argumento, Delgado examina as diferenças entre as obras de Campomanes, especialmente as Reflexiones sobre el comercio español a Indias de 1762 e o Discurso sobre el fomento de la industria popular de 1774.

24 Segundo consta em informe de Floridablanca no dia seis de agosto de 1777, no qual ele recomendava aceitar as ofertas portuguesas, aduzindo a vantagem de que o acordo geraria discórdia entre Lisboa e Londres. Cf. Rico Bodelón, 2013: 622.

25 Tratado preliminar de límites en la América meridional, ajustado entre las coronas de España y de Portugal: firmado el 1o. de octubre de 1777 (Calvo, 1862: 131-158). 
rania dos territórios africanos e conferia-se aos «vassalos da coroa de Espanha» o direito de negociar nos «portos do rio Gabão, dos Camarões, de S. Domingos, Cabo Fermoso e outros daquele distrito». Nos artigos seguintes a coroa espanhola se comprometia a comprar, por um período de quatro anos, tabaco brasileiro para fazer o tráfico na costa da África ${ }^{26}$.

Os reformadores espanhóis, desde meados do século XVIII, estavam cientes da necessidade de alterar o sistema de abastecimento de escravos para as colônias espanholas. O Tratado de Alcáçovas, de 1479, associado a outras leis do início do século XVI, havia excluído a Espanha da possibilidade de comerciar escravos na costa africana. Carlos $\mathrm{V}$ inaugurou a prática de conferir licenças para a atividade como recompensa a súditos que prestassem serviços extraordinários à coroa. No fim do século XVI, com a união das coroas ibéricas, a Espanha instaurou os asientos, contratos negociados pela coroa e arrematados por comerciantes estrangeiros. Até a restauração de 1640, os asientos foram monopolizados pelos portugueses. Depois, holandeses e ingleses começaram a transportar escravos clandestinamente para as colônias espanholas, especialmente no Caribe. A partir da década de 1660, a coroa espanhola tentou relançar os asientos, que passaram a ser disputados acirradamente por genoveses, portugueses, holandeses, ingleses e franceses. A Compagnie de Guinée recebeu o contrato em 1701, mantido até a assinatura do tratado de Utrecht em 1713. A guerra de sucessão espanhola, na qual se confrontaram França e Inglaterra, também foi uma luta pelo domínio do comércio atlântico e do tráfico negreiro. A South Sea Company obteve o contrato por um período de trinta anos e, em 1721, foi autorizada a enviar escravos para o Alto Peru e o Chile através de Buenos Aires. Entretanto, os ingleses expandiram o contrabando com as colônias espanholas, aproveitando as permissões legais para a entrada de embarcações autorizadas pelo asiento. Tal situação deu margem a conflitos, que acabaram emergindo na Guerra da Orelha de Jenkins, iniciada em 1739 e encerrada em 1748. O tratado anglo-espanhol de 1750 determinou o fim do contrato para os britânicos em troca de uma indenização de cem mil libras. O fim do asiento dificultou o abastecimento de escravos e o contrabando voltou a prosperar, atingindo um ponto alto durante a Guerra dos Sete Anos, particularmente durante a ocupação britânica em Havana, quando mais de três mil escravos foram desembarcados em Cuba. Ao fim da guerra, ficou evidente para os reformadores espanhóis a necessidade de reorganizar o sistema militar, administrativo e comercial do império, incluindo o tráfico negreiro. O sucesso das ilhas açucareiras britânicas e francesas era o

26 Tratado de amistad, garantía y comercio, ajustado entre las coronas de España y de Portugal, y firmado el 24 de marzo de 1778 (Calvo, 1862: 168-191). 
exemplo a ser seguido em Cuba. Houve uma sintonia entre a oligarquia de Havana e os reformadores espanhóis em torno da necessidade de incrementar a importação de escravos africanos na ilha, embora não houvesse concordância acerca da melhor maneira de atingir este intento. Em 1765 foi concedido um contrato para a Compañía Gaditana de Negros, mas o alto preço dos escravos e a dificuldade em obter mercadorias adequadas para realizar o trato na costa africana determinaram o fracasso do empreendimento comercial. No início da década de 1770, a companhia foi reestruturada, alcançando melhores resultados, mas ainda assim insuficientes e dependentes da realização de parcerias com comerciantes britânicos ${ }^{27}$.

O fato é que os estadistas espanhóis percebiam a necessidade de reorganizar o tráfico negreiro, tanto para aumentar a disponibilidade de mão de obra escrava -não somente para Cuba, mas também para Porto Rico, Santo Domingo, costa caribenha do Vice-Reino da Nova Granada, Peru, Chile e Rio da Prata- como para incrementar os rendimentos da coroa por meio de um controle mais efetivo do negócio. A arrecadação obtida com os asientos e demais contratos era cada vez menor, e havia uma percepção, bastante fundamentada, de que esses mecanismos facilitavam demasiadamente a introdução de contrabando nas colônias. O problema todo era como mudar o sistema. Me parece que muitos reformadores julgavam que a solução ideal seria a nacionalização e a liberação do tráfico, isto é, a permissão geral para comerciantes espanhóis buscarem escravos na África e os levarem para as colônias. Assim, a oferta aumentaria, a coroa incrementaria sua arrecadação cobrando taxas sobre as transações, os lucros gerados pelo negócio circulariam no interior do império e os estrangeiros seriam afastados, criando dificuldades para o contrabando. Contudo, nas condições existentes na década de 1770, tal projeto era quimérico.

A questão foi debatida intensamente no marco das discussões sobre o comércio livre, tendo desdobramentos, como vimos, nas negociações pela paz com Portugal. Tomás Ortiz de Landázuri foi fundamental no processo legis-

27 O panorama sobre o tráfico de escravos no império espanhol está baseado principalmente em Delgado Ribas, 2013: 13-42; Sobre os asientos cf. Vila Vilar, 1973: 557-599. Para a Compañia Gaditana, cf. Torres Ramírez, 1973: 1-41 e 99-118. Sobre a sintonia entre a oligarquia cubana e os reformadores espanhóis cf. Berbel, Marquese e Parron, 2010: 75-79. Tornero Tinajero, 1996: 21-44. Embora identifique a aproximação dos proprietários e comerciantes cubanos com os estadistas metropolitanos, Tornero também enfatiza a existência de conflitos, particularmente sobre os meios que deveriam ser empregados para incrementar o fluxo de escravos na ilha. Francisco Arango y Parreño, o mais notável representante da oligarquia cubana, teve um papel decisivo nessa aproximação, especialmente a partir de fins da década de 1780. Cf. Piqueras Arenas, 2009: 151-166. González-Ripoll, 2001: 291-305. 
lativo reformista. Ele tivera um papel de destaque na elaboração do Decreto y Real Instrucción de 1765 para o livre comércio com as ilhas de Barlovento e também o teve na retomada, a partir de 1771, do programa reformista. Ele foi comissionado pelo Conselho de Índias para apresentar uma nova proposta de reforma do comércio, concluida em dezembro de $1776^{28}$. Nela, resumia as seis causas principais da decadência do comércio com a América: o monopólio de Cádiz, o sistema de frotas, o derecho de palmeo (tributo cobrado sobre o volume e não sobre o valor das mercadorias), a falta de escravos, o não cumprimento das leis sobre a produção têxtil e o plantio de vinhas e oliveiras e, por fim, o excesso de tributos sobre o ouro e a prata. Tratava-se de uma reelaboração, acrescida de cálculos, do texto proposto em 1765. Ortiz de Landázuri e Gálvez, que o apoiava, pretendiam vencer as resistências que ainda entravavam as mudanças. Mesmo assim, a proposta foi recusada em primeira instância. Em maio de 1777, José Pablo de Agüero escreveu um parecer, apoiado por outros membros da ala conservadora do Conselho, todos com sólidas conexões com o comércio gaditano, criticando uma a uma as soluções propostas por Ortiz ${ }^{29}$.

Agüero defendia a manutenção do monopólio de Cádiz, afirmando que o sistema vigente não prejudicava a distribuição dos bens americanos e não impedia a participação de grupos mercantis de outras cidades espanholas no comércio atlântico. A liberação dos portos seria prejudicial, pois abriria as comportas para os comerciantes estrangeiros. Para Ortiz de Landázuri, a falta de escravos ocasionava o despovoamento das colônias, entravando o desenvolvimento da agricultura. O recurso seria a entrada de navios espanhóis na África para realizar o comércio diretamente. Segundo Agüero, tal solução era tão fácil de propor como difícil de executar,

... pues apoderadas ya varias Naciones Europeas de los parajes precisos donde se trafican a cambio de frutos, quinquillería, y bujerías, que no tenemos propias, y estando hechos dueños absolutos de un Comercio tan lucrativo, a buen seguro que nos permitan entrar a la parte y por la regla de querer España abarcar todas las utilidades del Comercio universal, tirarían las Naciones unidas a despojarla de muchos de sus Dominios donde posee pacíficamente el oro, y la plata que la hace superior a ellas sin tantos riesgos ni fatigas ${ }^{30}$.

28 García-Baquero González, 2000-2001: 189-210.

29 Delgado Ribas, 2007: 388-391. Stein e Stein, 2003: 156-158.

30 Dictamen leído en Consejo pleno con asistencia de su Gobernador en 12 de Mayo de 1777. Sobre el Comercio de Indias, Archivo General de Indias, Sevilla (AGI), Estado, 86a, n. 14. 
Ademais, o tráfico não seria a melhor maneira de povoar as mais de 700 léguas de costa entre o Orinoco e o Cabo Catoche (Yucatán), pois nessa vasta região, alegava, eram raros os vecinos com recursos para adquirir escra$\operatorname{vos}^{31}$.

O impasse foi resolvido com a convocação, em julho, de uma nova sessão do Conselho de Índias, agora pleníssima. Aprovou-se a proposta de Ortiz de Landázuri com algumas modificações, baseadas no voto do conselheiro Fernando Magallón. Ele contestou as objeções interpostas por Agüero e defendeu o fim do monopólio gaditano, a extensão para todas as províncias espanholas do direito de realizar o comércio diretamente com a América, a redução de impostos e de formalidades administrativas no trânsito das embarcações, o favorecimento do comércio e da navegação de zonas mais pobres da América e a diminuição dos tributos sobre a prata e o ouro. Embora concordasse em acabar com o monopólio gaditano, achava ainda necessário manter o sistema de frotas no comércio com a Nova Espanha, pois seria arriscado suprimi-lo repentinamente. Magallón também criticava duas propostas de Ortiz, cuja aplicação não seria conveniente naquele momento: a proibição do plantio de vinhas na América e a livre introdução de escravos buscados diretamente na África ${ }^{32}$. Sobre o último ponto, o conselheiro afirmava que a medida era importantíssima e traria vantagens consideráveis para a nação, mas no «estado y posesión en que se hallan hoy las naciones de Europa en aquellas costas, lo hace si no imposible, a lo menos muy difícil; casi todas ellas tienen factorías y establecimientos en los más de los Puertos conocidos y dificultosamente permitirían la concurrencia de otra Nación». Ele lamentava o fato de que a Espanha não participava do tráfico: «cosa vergonzosa que nosotros que tenemos tanta necesidad de los negros, seamos los únicos entre las Naciones marítimas y negociantes que no hayamos tenido arte ni modo para hacer en derechura este comercio». Para Magallón, os portugueses, que faziam comércio direto do Brasil à África, eram um exemplo a seguir, mas, ponderava, talvez já fosse tarde para «pensar en entrar a la parte con ellos, a menos que algún rompimiento con esta Nación nos dé ocasión de pensar en tomar medidas bien combinadas para despojarlos de aquel tráfico» ${ }^{33}$. Segundo Antonio García-Baquero, a proposta de Magallón teve impacto doutrinário e suas objeções foram levadas em consideração, tanto que a proibição de plantar vinhas e a livre introdução de escravos da África não constavam do texto definitivo

\footnotetext{
31 Idem.

32 García-Baquero González, 2000-2001: 203-205.

33 Extracto y Minuta de la Consulta del Consejo de Indias sobre Comercio libre, 14 de Julio de 1777, AGI, Indiferente General (IG), 2409.
} 
do Reglamento y Aranceles para el Comercio Libre, publicado no dia doze de outubro de $1778^{34}$. Josep Delgado, por outro lado, afirma que o parecer de Magallón, um alto burocrata ligado à Secretaria de Estado, sem peso no Conselho de Índias e praticamente nenhuma experiência nos assuntos americanos, simplesmente refletia as opiniões de Floridablanca e Campomanes, não necessariamente coincidentes às de Ortiz de Landázuri. Justamente os dois pontos sobre os quais a administração reformista de Carlos III tinha dúvidas, isto é, a inclusão formal da Nova Espanha no novo sistema e a liberação do comércio de escravos, foram criticados por Magallón e depois retirados do Reglamento ${ }^{35}$.

UMA FEITORIA PARA O TRÁFICO DE ESCRAVOS: EXPECTATIVAS, PROJETOS E OBSTÁCULOS

Floridablanca, Campomanes, Gálvez e outros ilustrados sabiam que seria complicado para a Espanha participar diretamente do tráfico de escravos na costa da África. Havia uma série de obstáculos: inexperiência dos comerciantes espanhóis; falta de produtos para negociar com os africanos; temor de que estrangeiros, particularmente os britânicos, empregassem espanhóis como prepostos para introduzirem escravos e mercadorias contrabandeadas; receio de que as potências europeias opusessem resistência; incerteza sobre qual modelo geraria maior arrecadação tributária, a liberação ou a criação de companhias com direitos exclusivos; e, por fim, a inexistência de possessões na costa africana adequadas ao estabelecimento de feitorias e portos de trato.

Floridablanca e Gálvez, contudo, estavam convencidos a não desistir facilmente. Pelo menos uma das dificuldades eles acreditavam ter superado, com a obtenção de Fernando Pó e Ano Bom. Após a assinatura do Tratado de Santo Ildefonso, eles se moveram com rapidez na preparação de uma expedição, que sairia de Montevidéu, para tomar posse das ilhas e assentar um estabelecimento. Nos dias nove e vinte de outubro, Gálvez emitiu instruções reservadas ao vice-rei em Buenos-Aires, que depois as entregaria ao chefe da expedição. Lisboa mandaria para o golfo da Guiné uma embarcação chefiada por um oficial que carregaria instruções para a transferência de posse, bem como novas informações com detalhes sobre os portos e os direitos cedidos. Também foi exigido dos chefes da expedição absoluto silêncio sobre a missão, cuja justificativa seria a realização de operações de reconhecimento na costa

\footnotetext{
34 García-Baquero González, 2000-2001: 208-209.

35 Delgado Ribas, 2007: 396-398.
} 
da América do Sul. No dia dezessete de abril de 1778, a expedição partiu de Montevidéu, tendo como chefe o conde de Argelejo, nomeado governador e comandante militar das ilhas. O comandante da esquadra era José Varela y Ulloa e o do exército Joaquín Primo de Rivera. A expedição foi um tremendo fracasso. Os portugueses não se mostraram dispostos a colaborar e, ainda por cima, tinham oferecido informações duvidosas a respeito das ilhas de Fernando Pó e Ano Bom. Os espanhóis se viram às voltas com doenças, falta de alimentos, conflitos entre os oficiais, motins, deserções, resistência das populações locais e até um bloqueio imposto por navios de guerra britânicos. O conde de Argelejo morreu vitimado por uma febre e Primo de Rivera assumiu o comando. Mesmo tendo recebido víveres e dinheiro enviados da Espanha e de Buenos Aires, não foi possível organizar um estabelecimento em Fernando Pó. O que restava da expedição partiu para São Tomé em fins de 1780, onde ficou mais um ano até rumar para a Bahia, retornando a Montevidéu em fevereiro de 1783. Voltaram pouco mais de sessenta indivíduos, dos cerca de trezentos que participaram do esforço colonizador -somando os que partiram originalmente de Montevidéu com alguns artesãos canarinos e um grupo de sessenta escravos comprados por Primo de Rivera ${ }^{36}$.

O que explica o fracasso da expedição e dos planos posteriores de colonização das ilhas cedidas pelos portugueses? Ano Bom é uma ilha muito pequena, distante $400 \mathrm{~km}$ do Cabo López, com pouquíssima terra cultivável. Fernando Pó, por outro lado, é bastante extensa, localizada na baía de Biafra (atualmente baía de Bonny), a $30 \mathrm{~km}$ de Bimbia e $70 \mathrm{~km}$ de Calabar. Embora não contasse com grandes extensões de terra cultivável, possuía água e madeira em abundância ${ }^{37}$. Os espanhóis consideraram Fernando Pó mais adequada para o estabelecimento de uma feitoria, mas logo identificaram problemas. A navegação até a costa, a despeito da pequena distância, era muito difícil, por causa das correntes e ventos. Não havia um porto natural adequado e o escolhido era vulnerável a ataques. A ilha era habitada pelos Bubi, um povo que tinha pouco contato com os europeus, o que dificultava a formação de alianças. Talvez por isso as visões europeias sobre eles eram predominantemente negativas, acusando-os de falarem uma língua bárbara e serem selvagens e cruéis. Os Bubi realmente opuseram resistência aos espanhóis, principalmente porque não queriam provê-los de alimentos e auxílio. Também existia na ilha uma comunidade de escravos fugitivos do Príncipe e de São Tomé que, com razão, temiam que os espanhóis pudessem reescravizá-los.

\footnotetext{
36 García Cantús, 2004: 39-72. Crespi, 2010: 1-34.

37 García Cantús, 2004: 40-41.
} 
Por fim, como se não bastasse, a malária era um grave problema e ceifou a vida de muitos dos membros da expedição ${ }^{38}$.

Ainda que esses obstáculos tenham colocado dificuldades, eles poderiam ter sido superados, não fossem razões mais poderosas. A primeira delas era a falta de experiência dos espanhóis no tráfico, somada ao fato de que eles não tinham acesso às mercadorias adequadas para fazer negócios com os africanos. Isso valia tanto para a compra de escravos quanto para a obtenção de víveres e pagamento por força de trabalho local.

O funcionamento do tráfico também trouxe dificuldades. Os espanhóis cobiçaram Fernando Pó por sua localização na baía de Biafra, zona tradicional da trata negreira. A área cujos direitos de comércio os portugueses repassaram era limitada ao norte pelo cabo Formoso, no delta do Níger, e ao sul pelo cabo López, correspondendo hoje a todo o litoral do Camarões e da Guiné Equatorial e a parte das costas da Nigéria e do Gabão. No entanto, os melhores portos da baía de Biafra estavam sob domínio inglês. Os principais eram Calabar (ou Velho Calabar), Novo Calabar e Bonny, de onde saíram aproximadamente 400 mil escravos entre 1730 e 1776, sendo $90 \%$ transportados pelos britânicos ${ }^{39}$. Os portos onde os espanhóis poderiam atuar (Bimbia, Camarões, Gabão, Corisco e Cabo López) respondiam por uma parcela minoritária do movimento ${ }^{40}$. Neles não havia comunidades mercantis estabelecidas que pudessem atrair as redes negreiras do interior. Os próprios portugueses, a partir de suas bases em São Tomé e Príncipe, preferiam operar ao sul do Cabo López, na região do Congo e Angola. Outro fato importante é que os portos dominados pelos ingleses na baía de Biafra experimentaram um grande aumento da atividade a partir da década de 1750. A vasta área dos Camarões e do Gabão, até então praticamente ignorada, foi empurrada para as redes do tráfico negreiro britânico e, secundariamente, francês e holandês. As fontes de escravos no interior foram, em grande parte, drenadas para Calabar, Novo Calabar e Bonny ${ }^{41}$.

Os primeiros contatos travados pelos espanhóis logo após a sua chegada no Golfo da Guiné já traziam indicações de que os portugueses tinham oferecido falsas informações e uma perspectiva completamente irrealista da pos-

38 Sundiata, 1996: 10-20.

39 Voyages, The Trans-Atlantic Slave Trade Database, http://www.slavevoyages.org (acessado no dia 06 de dezembro de 2013).

40 Eltis e Richardson, 1997: 22.

41 Sobre a atividade dos britânicos e a ligação entre Camarões e Calabar cf. Nwokeji e Eltis, 2002: 191-210. Austen e Derrick, 1999: 23-40. A atuação de negreiros ingleses nos Camarões começou justamente na década de 1780, cf. Behrendt, 1997: 201-203. 
sibilidade de atuação no tráfico negreiro a partir de Fernando Pó e Ano Bom. Com tom bastante pessimista, o conde de Argelejo escreveu um parecer destinado a Gálvez em setembro de 1778. Afirmava, em resumo, que as ilhas pouco poderiam produzir em benefício do Estado, em virtude das despesas necessárias para sua manutenção. Ainda assim, recomendava a instalação de uma feitoria na ilha de Fernando Pó e propunha a criação de uma companhia, sob a proteção do soberano. Os gastos deveriam ser cobertos pelos acionistas e, em contrapartida, a coroa cobraria tributos moderados sobre as transações. Argelejo finalizava seu parecer reiterando a dificuldade de comprar escravos em grande quantidade naquela área. Era preciso percorrer diversos portos em pequenas balandras e transportar gradualmente os escravos até Fernando Pó, onde eles seriam refrescados e bem tratados, evitando assim doenças e mortes antes de seu embarque para a América ${ }^{42}$.

Dois anos depois, José Varela y Ulloa redigiu um par de relatos com informações sobre as ilhas, nos quais manifestava toda a sua decepção. Ele desaconselhava a instalação de um estabelecimento em Fernando Pó, apesar de sua boa localização, por uma série de motivos, como a falta de um porto adequado, a resistência dos habitantes locais e a dificuldade na obtenção de víveres. O maior problema, porém, residia na configuração mercantil da região, pois os direitos de comércio cedidos pelos portugueses eram inexistentes. Varela afirmava que a Corte de Lisboa cometera uma fraude nas negociações. Segundo ele, no Cabo Formoso não existiam estabelecimentos europeus e jamais apareciam embarcações do tráfico, e tampouco havia comércio de escravos desde que se descobrira o Golfo do Benim. O comércio do rio Camarões era desprezível, exigindo quatro ou cinco meses para comprar algumas dezenas de escravos. A barra era perigosa e só podia ser cruzada com embarcações pequenas, que ficavam expostas a «mil acidentes da parte dos negros». $\mathrm{O}$ rio de Santo Domingo (mencionado no tratado como S. Domingos) não existia, a menos que tivesse sido renomeado. O comércio do Gabão era livre e dele participavam franceses, ingleses e holandeses, que por serem os mais fortes ditavam a lei em todos os assuntos relativos ao tráfico. Assim, todo o comércio de Fernando Pó se reduzia ao rio Gabão, onde os espanhóis iriam sofrer uma concorrência implacável dos estrangeiros. Os lucros a serem auferidos não seriam suficientes para cobrir as despesas da instalação de um domínio espanhol na ilha. Para concluir, Varela asseverava que os portugueses jamais haviam se estabelecido em Fernando Pó e sequer faziam o mais leve

42 Parecer del Brigadier Conde de Argelejo sobre la posesión de las Islas de Annobon, y Fernando Pó en la Costa de Guinea, y los fines que se ha propuesto la Corte para estos establecimientos, Ilha do Príncipe, 15 de Setembro de 1778, AGI, Buenos Aires (BA), 41. 
comércio com seus habitantes. O mesmo podia ser dito da costa, «com a notável particularidade de que no rio Camarões, no rio Gabão e na enseada de Lope Gonzalvo [Cabo López], desde muito tempo se olha com bastante desprezo a bandeira de Portugal» ${ }^{43}$. Ele recomendava exigir dos portugueses a ilha do Príncipe, ou ao menos a permissão para nela se estabelecer, de modo que, utilizando-a como base, os espanhóis pudessem construir uma fortaleza no Gabão para assegurar o comércio de escravos até o Cabo López. Do Príncipe eles também poderiam enviar embarcações aos portos de Tudá [sic], onde seria possível comerciar clandestinamente, tal como praticavam com muito sucesso os ingleses, holandeses e dinamarqueses ${ }^{44}$.

A última razão que explica o malogro espanhol é encontrada no quadro das relações internacionais. Enquanto a expedição de Argelejo ainda estava na Guiné, a Espanha se envolveu na Revolução Americana, entrando em guerra contra a Inglaterra. As atenções se voltaram para o conflito e o projeto ficou em segundo plano. Alguns anos depois, a Revolução Francesa desestabilizaria completamente o poder de intervenção da Espanha no sistema interestatal e suas consequências teriam impacto profundo em todo o comércio atlântico. As guerras europeias prejudicaram não somente os espanhóis mas também afetaram o próprio tráfico nas baías de Biafra e de Benim. Houve uma queda brusca nos embarques no Gabão, Bimbia, Camarões, Corisco e Cabo López. Entre 1762 e 1786, quase 31 mil escravos saíram da área, mas entre 1787 e 1811 o movimento despencou para 4,7 mil ${ }^{45}$.

Apesar do fracasso da expedição de Argelejo, foram realizadas novas tentativas de reorganizar o tráfico negreiro espanhol. Floridablanca e Gálvez pareciam estar inclinados, num primeiro momento, a nacionalizar o negócio por meio de uma companhia com direitos de monopólio, que teria a vantagem de poder utilizar as recém-adquiridas ilhas africanas para estabelecer feitorias e portos. Ainda em 1778, Gálvez, o responsável pelo projeto, recebeu duas propostas para desenvolver o tráfico na costa africana ${ }^{46}$.

A primeira delas era de autoria de Manuel Joseph de Orezuela, um espanhol natural do porto de Callao, no Peru. Comerciante com vasta experiência na navegação pelo Pacífico, conhecedor dos circuitos de venda de escravos

43 Descripción de la Isla de Fernando Poo hecha por el Capitán de Fragata y de la Marina Real Española Don José Varela, Año de 1780, documento transcrito por García Cantús, 2004: 629-631. Tradução livre de minha autoria.

44 Descripción de la Isla de Annobón, hecha por el Capitán de la Marina Real Española Don José Varela, 1780, apud García Cantús, 2004: 53. Acredito que, por Tudá, Varela se referia a Ajudá (Ouidah).

45 Eltis e Richardson, 1997: 26-29.

46 Vilar, 1971: 295-325. 
em Buenos Aires, Colônia do Sacramento, Chile, Lima e províncias interiores do Peru, Orezuela ofereceu a Gálvez um «Informe sobre el comercio de Negros Bozales, desde Guinea a Buenos Aires $\gg{ }^{47}$. Ele sugeria que a maneira mais prática e lucrativa para abastecer de escravos o Peru e o Rio da Prata no curto prazo era a liberação do comércio com os portugueses, por eles serem muito experimentados no tráfico negreiro, um negócio que exigia altos investimentos, um corpo de comerciantes qualificados e apresentava riscos consideráveis. Contudo, sabedor do desejo do rei Carlos III de adquirir os africanos em primeira mão, propunha que a coroa monopolizasse o negócio, comprando por sua conta e risco os escravos na Guiné e transportando-os para o Caribe e o Rio da Prata. Nos portos de destino, os cativos seriam vendidos a preços subsidiados para comerciantes que posteriormente os revenderiam, com lucro, aos proprietários. Para Orezuela, essas duas alternativas eram as únicas factíveis, pois a Espanha não contava com grupos de comerciantes, quer nas colônias, quer no reino, com capacidade para exercer a atividade ${ }^{48}$. Creio que Orezuela desejava obter licenças para comprar escravos dos portugueses no Brasil, particularmente no Rio de Janeiro, com o propósito de revendê-los no Rio da Prata, se inserindo num circuito mercantil altamente lucrativo do Atlântico Sul. Por isso ele punha em relevo as dificuldades que os espanhóis teriam para participar do tráfico, ao mesmo tempo em que realçava as vantagens de negociar com os portugueses. Ao afirmar que o controle direto da coroa, prática que não era seguida por nenhuma outra nação, era o único meio da Espanha participar do comércio transatlântico de escravos, julgo que Orezuela pensava estar reforçando a alternativa que realmente lhe interessava.

José de Oliveira Pedroso, um comerciante português, era o autor da segunda proposta encaminhada a Gálvez ${ }^{49}$. Ele sugeria o estabelecimento de três feitores gerais em Fernando Pó, Ano Bom e Cabo López, além de uma casa forte em Ajudá. Os escravos adquiridos em Ajudá seriam conduzidos a Fernando Pó e os obtidos em Cabo López e arredores teriam como destino Ano Bom. O tabaco brasileiro seria o meio de pagamento dos escravos, os quais seriam levados para dois destinos nas Américas, Buenos Aires e Portobelo,

47 Informe sobre el comercio de Negros Bozales, desde Guinea a Buenos Aires, Madrid, 18 de agosto de 1778, AGI, IG, 1565, O documento é acompanhado por uma relação de méritos, datada de 15 de novembro de 1776, e duas cartas destinadas a Gálvez, de 21 de junho e 29 de setembro de 1778 .

48 «En el bien entendido de que no habiendo en España quien lo practique, menos hay espíritu, ni facultades en las Indias para su ejecución» (idem).

49 Documento sem título, projeto de Joze d'Oliveira Pedrozo, Madrid, 25 de junho de 1778, AGI, IG, 1565. 
de onde seriam redistribuídos. Para a consecução do plano era necessário criar uma companhia geral com direitos exclusivos, pois somente com a reunião de capitais seria possível financiar a instalação da infraestrutura exigida. Pedroso dizia que «as Companhias [...] são no Comércio o que [são] as Alianças em Política, e a União das Forças em Mecânica». Ele mirava o exemplo de sucesso do Estado do Grão Pará e Maranhão onde, após a criação de uma companhia geral pelo marquês de Pombal e a introdução contínua de grandes levas de escravos, ocorreu um crescimento formidável da agricultura de exportação, particularmente de algodão, arroz, cacau e café.

Alguns anos depois, quando a primeira experiência de colonização das ilhas africanas já havia naufragado, uma nova proposta chegou ao conhecimento de Gálvez por intermédio de Floridablanca, que por sua vez a recebera das mãos de Juan Antonio Archimbaud, um burocrata pertencente ao seu círculo de relações. O autor era um comerciante e capitão de navio francês, M. Eyries, protegido do Duque de Crillon ${ }^{50}$. Eyries, já informado do fracasso da expedição de Argelejo, acreditava que a Espanha deveria explorar outros lugares para estabelecer feitorias, como Bissau, Iles de Los e a Costa do Ouro. Crillon assegurava que Eyries era a pessoa certa para organizar o empreendimento, por ter larga experiência adquirida durante dez anos de permanência na costa da Guiné tratando dos interesses da Compagnie de la Guyane ${ }^{51}$ e de negociantes de Nantes e Bordeaux. Eyries recomendava a criação de uma companhia protegida, que poderia explorar o comércio de escravos e de outros artigos, como marfim, goma, cera e arroz.

Gálvez não deu continuidade a nenhuma dessas propostas, provavelmente por não apresentarem informações verdadeiramente relevantes e também por seus autores não estarem representando algum grupo mercantil bem conectado que efetivamente significasse uma aliança vantajosa para a coroa espanhola. Apesar disso, o modelo de organização proposto por Pedroso e Eyries, uma companhia com direitos exclusivos, parecia também ao ministro de Índias o meio mais eficaz de desenvolver o projeto. Em 1785 a Compañia de Filipinas

50 Trata-se de um conjunto de documentos, redigidos em francês e em espanhol, formado por cartas, um projeto, uma projeção de despesas, faturamento e lucros e uma relação de portos e mercadorias para realizar o tráfico de escravos, desde Bissau até o Cabo López. Proyecto de M. de Eyries sobre un Establecimiento en la Costa de África para el Comercio de Negros. Remitido y recomendado por el Duque de Crillon, AGI, IG, 1565. A data do primeiro documento é 01/02/1782 e a do último é 15/04/1784.

51 Criada em 1776 e depois refundada como Compagnie du Sénégal. Cf. MarchandThébault, 1960: 5-75. 
foi refundada, tendo Gálvez como diretor ${ }^{52}$. Pensava-se em utilizar a ilha de Fernando Pó como um porto de escala para as embarcações que vinham da Ásia, seja pelo Cabo Horn ou pelo Cabo da Boa Esperança. Com mercadorias trazidas do oriente, pretendia-se comprar escravos que depois seriam transportados, em outras embarcações, para as colônias. Ciente da falta de experiência dos comerciantes espanhóis, agentes foram enviados a Londres e Liverpool para conhecerem detalhes do negócio, particularmente os equipamentos e a maneira como eram organizados os navios negreiros ${ }^{53}$. A Compañía de Filipinas entrou em operações, mas os resultados não foram muito auspiciosos. Tal como ocorrera com a Compañía Gaditana, sofreu prejuízos e dependeu de parcerias com companhias britânicas para realizar o comércio de escravos.

No ano de 1787, houve uma mudança de rumos, não apenas na política para o tráfico negreiro mas igualmente nas diretrizes para o comércio colonial. Os primeiros anos após a aprovação do «comercio libre» foram exitosos, muito em razão das vantagens que a Espanha obteve durante a guerra de independência dos Estados Unidos, quando França e Grã-Bretanha estavam em posição delicada. Porém, a partir de 1786 verificou-se uma saturação de produtos europeus nos mercados americanos, de modo que o comércio colonial espanhol passou a operar com lucros muito baixos e até prejuízos. A morte de Gálvez, em 1787, permitiu que a administração espanhola reconhecesse a gravidade da crise. Floridablanca preparou um novo conjunto de reformas: dividiu a Secretaria de Índias, criou a Junta Suprema de Estado, incluiu a Nova Espanha no sistema do «comercio libre», aumentou o número de portos habilitados, facilitou o comércio intercolonial e reduziu a pressão fiscal sobre produtos americanos ${ }^{54}$.

Nessa nova onda de reformas, foi liberado o tráfico de escravos, primeiro para Cuba e Porto Rico em 1789 e, depois, para o Rio da Prata, o Chile e o Peru em 1791. A medida, provisória, foi estendida diversas vezes. Ela teve efeitos importantes, pois aumentou substancialmente a importação de escravos pelas colônias espanholas, tanto no Caribe como na América do Sul. A presença de espanhóis no comércio negreiro, por outro lado, não recebeu impul-

52 Gálvez já pensava em conceder direitos de comércio nas ilhas de Ano Bom e Fernando Pó à Compañía de Filipinas desde 1778, quando ele definira dois objetivos para a expedição de Argelejo: desenvolver o comércio de escravos e fundar um porto para escala e abrigo das embarcações das Filipinas (Parecer del Brigadier Conde de Argelejo..., Ilha do Príncipe, 15 de Setembro de 1778, AGI, BA, 41).

53 Eltis, 1987: 52.

54 Delgado Ribas, 2007, caps. 12 e 13. 
so significativo e a dependência dos estrangeiros, quer britânicos no Caribe, quer portugueses no Rio da Prata, se manteve. Tal situação só mudaria após a proibição do tráfico atlântico pela Grã-Bretanha e pelos Estados Unidos, em 1807 e $1808^{55}$.

CONCLUSÃO: TRÁFICO NEGREIRO, SISTEMA INTERESTATAL E A POLÍTICA COLONIAL DOS IMPÉRIOS IBÉRICOS

As negociações para elaboração do Tratado de Santo Ildefonso se aceleraram após a morte do rei D. José I e a queda do marquês de Pombal, nos primeiros meses de 1777. Francisco Inocêncio de Sousa Coutinho, embaixador português em Madri, tratava diretamente com o conde de Floridablanca. Entre outros pontos polêmicos, a cessão das ilhas africanas logo entrou em pauta. Talvez tenha sido o próprio Sousa Coutinho a sugerir a entrega de Fernando Pó e Ano Bom, de cuja situação ele certamente estava informado por ter sido governador de Angola entre 1764 e 1772. O espanhol mencionava, em conversas informais, o desejo do rei Carlos III de obter um «buraco» ou uma «bicoca» ${ }^{56}$ na África, para traficar escravos ${ }^{57}$.

Aires de Sá e Melo, secretário de negócios estrangeiros que assumira também a secretaria de estado no lugar de Pombal, instruiu enfaticamente o embaixador português a valorizar a cessão das possessões africanas nos colóquios com Floridablanca. O espanhol aparentemente agia de forma contraditória exigindo garantias e celeridade na conclusão do acordo e, ao mesmo tempo, tratando o assunto com jocosidade e desprezo ${ }^{58}$.

O secretário de estado português entendia que Floridablanca assim procedia para «diminuir o preço» da concessão oferecida. Por isso, Sousa Coutinho deveria «fazer observar em toda a ocasião [...] o quanto vale a Espanha o pretendido buraco na costa de África». Sá e Melo lembrava que a Espanha jamais tivera um estabelecimento no continente e sempre dependera dos asien-

55 Murray, 2002: 11-21.

56 Bicoca: «Según Covarrubias en su Tesoro es una torrecilla de madera hecha a modo de garita, donde se guarece el soldado de los temporales, cuando hace la centinela»; "Cosa de poca estima y aprecio, y así se dice: eso es una bicoca» (Real Academia Española, 1770: 482).

57 Ofício de Aires de Sá e Melo a Francisco Inocêncio de Sousa Coutinho, Palácio de N. S. da Ajuda, 24 de maio de 1777, Arquivo Nacional da Torre do Tombo, Lisboa (ANTT), Ministério dos Negócios Estrangeiros (MNE), caixa 615.

58 Ofícios de Aires de Sá e Melo a Francisco Inocêncio de Sousa Coutinho, datados de 3 de junho e 26 de julho de 1777, ANTT, MNE, caixa 615. 
tos para abastecer com escravos suas colônias americanas. Obter um território na África teria uma «utilidade imensa», sem comparação «com mais ou menos léguas de terra na América». Além disso, o acordo teria consequências para Portugal, porque ficariam «ofendidas todas as potências que negociam em escravos». Por isso, recomendava que os artigos sobre a cessão das ilhas africanas e o acordo comercial deveriam permanecer secretos, pois assim que Paris e Londres fossem informadas seus governos tentariam «atravessar os ajustes». O secretário de estado português concluía afirmando que, da parte de Sua Majestade Fidelíssima, não havia perigo de «mudar de sistema», mas era importante manter o segredo para «acautelar prudentemente as baterias e assaltos com que seríamos atacados uns e outros pelas potências interessadas» ${ }^{59}$.

A missiva de Aires de Sá e Melo resumia os dilemas geopolíticos enfrentados pela Espanha no processo de reforma de seu sistema mercantil e na tentativa de abocanhar um naco do lucrativo e estratégico comércio negreiro transatlântico. Não se tratava apenas de falta de experiência no negócio ou de conhecimento dos mercados, de dificuldade em reunir capitais ou de obter as mercadorias e os equipamentos necessários para transacionar escravos com eficiência e baixo custo. Em outras palavras, o problema da Espanha não era apenas a incapacidade de seus comerciantes enfrentarem com sucesso a concorrência econômica dos estrangeiros. Havia também o problema político da competição entre os Estados europeus.

A integração das dinâmicas da economia-mundo e do sistema interestatal se torna evidente quando se trata de explicar o tráfico transatlântico de escravos. Desde seu início o comércio negreiro foi muito mais do que mera consequência da demanda por mão de obra no Novo Mundo. Ele se tornou um instrumento crucial da política colonial dos impérios atlânticos. Inglaterra e França disputaram palmo a palmo a hegemonia no mundo atlântico desde o fim do século XVII. Nesse embate, o controle dos asientos tinha uma grande importância, pois além de lucrativo, abria uma brecha para os mercados coloniais da América espanhola.

Após a Guerra dos Sete Anos, surgiram oportunidades para que Portugal e Espanha promovessem reformas que visavam o aumento da arrecadação para os cofres régios, a modernização de seus sistemas comerciais e a consolidação territorial de seus domínios. O tráfico negreiro tinha, nesse contexto, um papel relevante, principalmente para a Espanha que buscava igualar experiências coloniais de sucesso dos impérios rivais, baseadas na agricultura

59 Ofício de Aires de Sá e Melo a Francisco Inocêncio de Sousa Coutinho, Belas, 26 de julho de 1777, ANTT, MNE, caixa 615. 
escravista de exportação. No entanto, a nacionalização do tráfico, embora em teoria fosse a solução ideal para erigir barreiras ao contrabando e estimular a agricultura, o comércio e o povoamento das colônias americanas, na prática se chocava com interesses enraizados dentro e fora do império.

Tal cenário obrigou os reformadores espanhóis a adaptarem seus planos. Na década de 1770, três frentes de atuação a princípio distintas da administração de Carlos III se combinaram: a reforma do sistema comercial, o contencioso das fronteiras no Novo Mundo e a nacionalização do tráfico de escravos. Floridablanca e Gálvez subordinaram a expansão dos domínios espanhóis aos outros dois objetivos, obtendo as ilhas africanas e a aproximação com Portugal ao custo da devolução de territórios na América do Sul. O fim do monopólio de Cádiz foi a principal medida incluída no Reglamento de Comercio Libre de 1778. A liberação do comércio negreiro foi adiada e buscou-se, primeiro, saídas conservadoras com a criação de companhias monopolistas. Os administradores de Carlos III temiam que Inglaterra e França criassem dificuldades ou que os negociantes espanhóis fossem incapazes de operar com autonomia, sendo obrigados a se associarem com estrangeiros que aproveitariam para quebrar de vez o já combalido exclusivo comercial.

Passados mais de dez anos, tendo amargado o insucesso da política para o tráfico atlântico e vendo sinais de esgotamento nos resultados gerados pelo Reglamento, Floridablanca inauguraria uma nova onda de reformas ao liberar o comércio negreiro. O secretário de estado percebera que uma bicoca na costa da África não era suficiente para incorporar o império espanhol ao pujante escravismo atlântico. Não por acaso, foi somente após a crise provocada pela Revolução de Saint-Domingue ter desestabilizado o escravismo no Atlântico Norte que a Espanha encontraria brechas para finalmente se emparelhar aos impérios coloniais escravistas, justamente quando estes caminhavam rumo à extinção.

\section{BIBLIOGRAFIA}

Adelman, Jeremy, Sovereignty and revolution in the Iberian Atlantic, Princeton, Princeton University Press, 2006.

Alden, Dauril, "The undeclared war of 1773-1777: climax of Luso-Spanish Platine rivalry", The Hispanic American Historical Review, XLI/1 (Durham, 1961): 55-74.

Alden, Dauril, "O período final do Brasil Colônia, 1750-1808”, Leslie Bethell (ed.), História da América Latina, v. 2, São Paulo/Brasília, Edusp/Fundação Alexandre de Gusmão, 2004: 527-592. 
Alencastro, Luiz Felipe de, O trato dos viventes: formação do Brasil no Atlântico Sul, São Paulo, Companhia das Letras, 2000.

Anderson, Perry, Linhagens do Estado absolutista, São Paulo, Brasiliense, 1995.

Arrighi, Giovanni, "The three hegemonies of historical capitalism", Stephen Gill (ed.), Gramsci, historical materialism, and international relations, Cambridge, Cambridge University Press, 1993: 148-185.

Arrighi, Giovanni, O longo século XX. Dinheiro, poder e as origens de nosso tempo, Rio de Janeiro/São Paulo, Contraponto/Editora UNESP, 1996.

Arruda, José Jobson de A., O Brasil no comércio colonial, São Paulo, Editora Ática, 1980.

Austen, Ralph A. e Derrick, Jonathan, Middlemen of the Cameroons Rivers: the Duala and their hinterland, c. 1600-c.1960, Cambridge, Cambridge University Press, 1999.

Behrendt, Stephen D., "The annual volume and regional distribution of the British slave trade, 1780-1807”, The Journal of African History, XXXVIII/2 (Cambridge, 1997): $187-211$.

Berbel, Márcia, Marquese, Rafael e Parron, Tâmis, Escravidão e política: Brasil e Cuba, c. 1790-1850, São Paulo, Hucitec, 2010.

Calvo, Carlos, Recueil Complet des Traités, conventions, capitulations, armistices et autres actes diplomatiques de tous les États de L'Amérique Latine, tome troisième, Paris, Durand, 1862.

Crespi, Liliana, "En busca de un enclave esclavista. La expedición colonizadora a las islas de Fernando Poo y Annobon, en el Golfo de Guinea (1778-1782)", Estudios Históricos/CDHRP, II/4 (Rivera, 2010): 1-34.

Delgado Ribas, Josep M., Dinámicas imperiales (1650-1796). España, América y Europa en el cambio institucional del sistema colonial español, Barcelona, Bellaterra, 2007.

Delgado Ribas, Josep M., "The slave trade in the Spanish empire (1501-1808). The shift from periphery to center", Josep Fradera e Christopher Schmidt-Nowara (eds.), Slavery and antislavery in Spain's Atlantic empire, Nova York, Berghahn, 2013: 13-42.

Elliott, J. H., Empires of the atlantic world. Britain and Spain in America, 1492-1830, New Haven, Yale University Press, 2006.

Eltis, D. Economic growth and the ending of the transatlantic slave trade, Oxford, Oxford University Press, 1987.

Eltis, D. e Richardson, D., "West Africa and the transatlantic slave trade: new evidence of long-run trends", Slavery \& Abolition, XVIII/1 (1997): 16-35. 
Ferrer del Rio, Antonio, Obras originales del Conde de Floridablanca y escrito referentes a su persona, Madrid, 1867.

García Cantús, Dolores, Fernando Poo: una aventura colonial española en el África Occidental (1778-1900), tesis doctoral, Valencia, Universitat de Valencia, 2004.

García-Baquero González, Antonio, "La consulta de 14 de julio de 1777 y el libre comercio: el decisivo voto del consejero Magallón", Trocadero: Revista de Historia Moderna y Contemporánea, XII-XIII (Cádiz, 2000-2001): 189-210.

Goes, Synesio Sampaio, Navegantes, bandeirantes, diplomatas, Brasília, IPRI, 1991.

González-Ripoll, María Dolores, "Vínculos y redes de poder entre Madrid y La Habana: Francisco Arango y Parreño (1765-1837), ideólogo y mediador", Revista de Indias, LXI/222 (Madrid, 2001): 291-305.

Hopkins, Terence K., "The study of the capitalist world-economy. Some introductory considerations", Terence Hopkins e Immanuel Wallerstein (eds.), World-system analysis: theory and methodology, Beverly Hills, CA, SAGE, 1982: 9-38.

Hopkins, Terence K. e Wallerstein, Immanuel, "Patterns of development of the modern world-system", Terence Hopkins e Immanuel Wallerstein (eds.), World-system analysis: theory and methodology, Beverly Hills, CA, SAGE, 1982: 41-82.

Kuethe, Allan J. e Andrien, Kenneth J., The Spanish Atlantic World in the Eighteenth Century. War and the Bourbon Reforms, 1713-1796, Nova York, Cambridge University Press, 2014.

Kuethe e Blaisdell, Lowell, "French influence and the origins of the Bourbon colonial reorganization", The Hispanic American Historical Review, LXXI/3 (Durham, 1991): 579-607.

Lucena Giraldo, Manuel, "La delimitación hispano-portuguesa y la frontera regional quiteña, 1777-1804", Procesos, Revista Ecuatoriana de Historia, IV (Quito, 1993): 21-39.

Marchand-Thébault, Marie-Louise, "L'esclavage en Guyane française sous l'ancien régime", Revue française d'histoire d'outre-mer, XLVII/166 (Paris, 1960): 5-75.

Maxwell, Kenneth, "Hegemonies old and new: the ibero-atlantic in the long eighteenth century", Jeremy Adelman (ed.), Colonial Legacies. The Problem of Persistence in Latin American History, Nova York, Routledge, 1999: 69-90.

Maxwell, Kenneth, Conflicts and conspiracies. Brazil and Portugal, 1750-1808, Nova York, Routledge, 2004.

Murray, David R., Odious commerce: Britain, Spain and the abolition of the Cuban slave trade, Cambridge, Cambridge University Press, 2002.

Novais, Fernando A., Portugal e Brasil na crise do antigo sistema colonial (17771808), São Paulo, Hucitec, 1989. 
Nwokeji, G. Ugo e Eltis, David, "Characteristics of captives leaving the Cameroons for the Americas, 1822-37”, The Journal of African History, XLIII/2 (Cambridge, 2002): 191-210.

Piqueras Arenas, José Antonio, "Los amigos de Arango en la Corte de Carlos IV", María Dolores González-Ripoll e Izaskun Álvarez Cuartero (eds.), Francisco Arango y la invención de la Cuba azucarera, Salamanca, Universidad de Salamanca, 2009: 151-166.

Pistone, Sergio, "Relações internacionais", Norberto Bobbio, Nicola Matteucci e Gianfranco Pasquino, Dicionário de política, vol. 2, Brasília, Editora UnB, 1997: 1089-1099.

Real Academia Española, Diccionario de la lengua castellana, tomo primero, A-B, Madrid, 1770.

Reis, Arthur Cezar Ferreira, "Os tratados de limites", Sérgio Buarque de Holanda (ed.), História geral da civilização brasileira. A época colonial, tomo I, vol. I, São Paulo, DIFEL, 1972: 368-379.

Rico Bodelón, Óscar, La ocupación española de Santa Catarina (1777-1778). Una isla brasileña para Carlos III, tesis doctoral, Salamanca, Universidad de Salamanca, 2013.

Stein, Stanley J. e Stein, Barbara H., Silver, trade, and war: Spain and America in the making of early modern Europe, Baltimore, The Johns Hopkins University Press, 2000.

Stein, Stanley J. e Stein, Barbara H., Apogee of empire: Spain and New Spain in the age of Charles III, 1759-1789, Baltimore, The Johns Hopkins University Press, 2003.

Sundiata, Ibrahim K., From slaving to neoslavery: the bight o Biafra and Fernando Po in the era of abolition, 1827-1930, Madison, University of Wisconsin Press, 1996.

Tilly, Charles, Coercion, capital, and European states, AD 990-1990, Cambridge, MA, Basil Blackwell, 1990.

Tornero Tinajero, Pablo, Crecimiento económico y transformaciones sociales. Esclavos, hacendados y comerciantes en la Cuba colonial (1760-1840), Madrid, Ministerio de Trabajo y Seguridad Social, 1996.

Torres Ramírez, Bibiano, La Compañia Gaditana de Negros, Sevilla, EEHA/CSIC, 1973.

Vila Vilar, Enriqueta, "Los asientos portugueses y el contrabando de negros", Anuario de Estudios Americanos, XXX (Sevilla, 1973): 557-599. 
Vilar, Sylvia, "Los predestinados de Guinea. Quelques raisonnements sur la traite des Noirs entre 1662 et 1780”, Mélanges de la Casa de Velázquez, VII (Madrid, 1971): 295-325.

Wallerstein, Immanuel, The modern world-system I. Capitalist agriculture and the origins of the European world-economy in the Sixteenth Century, Nova York, Academic Press, 1974.

Fecha de recepción: 13 de enero de 2015.

Fecha de aceptación: 13 de mayo de 2015.

\section{Una bicoca en la costa africana: la política española hacia el tráfico de esclavos, el Reglamento de Comercio Libre y las fronteras ibéricas en América del Sur (1776-1778)}

El Tratado de San Ildefonso, suscrito por España y Portugal en 1777, establecía la demarcación de límites entre los imperios ibéricos en el Nuevo Mundo. Algunas de sus cláusulas también determinaban la cesión a España de las islas portuguesas de Fernando Poo y Annobón, situadas en el Golfo de Guinea. Carlos III y su secretario de estado, Floridablanca, deseaban obtener un territorio en la costa de África con el fin de nacionalizar la trata de esclavos en el imperio español. Este artículo examina los intereses y las condiciones que suscitaron el acuerdo para traspaso de la soberanía de las islas africanas y analiza las razones que impidieron a España consolidar su participación en el comercio negrero. Se argumenta que para comprender la política española con respecto a la trata de esclavos en las décadas de 1770 y 1780 es necesario examinarla a la luz del proceso de elaboración del «Reglamento de Comercio Libre» y de los conflictos territoriales hispano-portugueses en la América del Sur.

Palabras Clave: comercio de esclavos; Tratado de San Ildefonso; reformismo borbónico; diplomacia. 


\section{An enclave on the coast of Africa: Spanish slave-trade policy, the Reglamento de Comercio Libre and South American borders} (1776-1778)

The Treaty of San Ildefonso, signed in 1777, defined the boundaries between the Spanish and Portuguese empires in the New World. Some of its terms also determined the transfer to Spain of the Portuguese islands of Fernando Pó and Ano Bom, located in the Gulf of Guinea. Charles III and his Secretary of State Floridablanca, wanted to acquire territory on the African coast in order to nationalize the slave trade in the Spanish Empire. This article explores the interests and conditions which led to the agreement and analyses the reasons that prevented Spain from consolidating its presence in the Atlantic slave trade. It argues that a proper examination of Spanish policy towards the slave trade during the 1770s and 1780s must also consider the process of preparation of the Decree of Free Trade and the territorial disputes between Spain and Portugal in South America.

KEY WORDs: slave trade; Treaty of San Ildefonso; Bourbon reforms; diplomacy. 